\title{
HUBUNGAN KONSEP DIRI DAN KECEMASAN DENGAN PENGAMBILAN KEPUTUSAN UNTUK BEROBAT KE DOKTER SPESIALIS (Penelitian Pada Pemanfaatan Program JPK PT. Jamsostek (Persero) Bandung I)
}

\author{
M. Nanang Suprayogi; Dyah Ayu Firsty \\ Jurusan Psikologi, Faculty of Humanity, BINUS University \\ Jln. Kemanggisan Ilir III No. 45, Kemanggisan-Palmerah, Jakarta Barat 11480
}

\begin{abstract}
This study aims to examine the relationship between self-concept and anxieties of the JPK PT. Jamsostek (Persero) participants who were ill with the decision to take advantage of the handling of the specialist physician. The measurement of self-concept used in this study is compiled based on the dimensions of self-concept developed by Fits, consisting of self-identity, self-behavioral, and self-judging. The measurement of anxiety refers to Mc Neil, et al, consisting of cognitive components, physiological responses, and behavior. The measurement of the decision-making refers to Hunsaker, et al, consisting of information complexity and level of focus. The study was conducted on 109 JPK participants treated at the hospital in the working area of PT. Jamsostek (Bandung I) with incidental purposive sampling technique. From the statistic test can be seen that there is a relationship between self-concept and decision making for treatment to a specialist. There is a relationship between anxieties with making the decision to go to a specialist. There is a relationship between self-concept and anxieties, together with the decision making to go to a specialist.
\end{abstract}

Keywords: self concept, anxiety, decision making

\begin{abstract}
ABSTRAK
Penelitian ini bertujuan untuk menguji hubungan antara konsep diri dan kecemasan peserta program JPK PT. Jamsostek (Persero) yang mengalami sakit dengan pengambilan keputusan untuk memanfaatkan penanganan dari dokter spesialis. Pengukuran konsep diri yang digunakan dalam penelitian ini disusun dengan mengacu pada dimensi konsep diri yang dikembangkan oleh Fits, terdiri dari identity self, behavioral self, dan judging self. Pengukuran kecemasan mengacu kepada Mc Neil, dkk, terdiri dari komponen kognitif, respon fisiologis, dan perilaku. Pengukuran pengambilan keputusan mengacu kepada Hunsaker, dkk, terdiri dari kompleksitas informasi dan tingkat fokus. Penelitian dilakukan terhadap 109 peserta program JPK yang berobat ke rumah sakit di wilayah kerja PT. Jamsostek (Bandung I) dengan teknik incidental purposive sampling. Dari uji statistik dapat dilihat ada hubungan antara konsep diri dengan pengambilan keputusan untuk berobat ke dokter spesialis. Ada hubungan antara kecemasan dengan pengambilan keputusan untuk berobat ke dokter spesialis. Ada hubungan antara konsep diri dan kecemasan secara bersama-sama dengan pengambilan keputusan untuk berobat ke dokter spesialis.
\end{abstract}

Kata kunci: konsep diri, kecemasan, pengambilan keputusan 


\section{PENDAHULUAN}

Fenomena yang dirasakan di PT Jamsostek (Persero) beberapa tahun terakhir menunjukkan angka kunjungan pasien ke dokter spesialis sangat tinggi di atas parameter yang telah ditetapkan peraturan nomor: SE/05/0596 Tentang Pengendalian Pemanfaatan Pelaksana Pelayanan Kesehatan (PPK). Di peraturan itu disebutkan bahwa parameter kunjungan ke dokter spesialis yang normal adalah berkisar antara angka $0.6 \%$ dan $0.8 \%$, serta angka rujukan dari PPK I ke rawat jalan dokter spesialis berkisar antara angka 3\% dan 6\%. Namun kenyataannya data menunjukkan bahwa angka kunjungan ke dokter spesialis selalu di atas parameter.

Dari tabel 1, dapat dilihat, bahwa ratio klaim PT. Jamsostek (Persero) cabang Bandung 1 selama 7 tahun belakangan ini selalu di atas standar yang telah ditentukan, bahkan menurut data ratio klaim pada tahun 2010 (Januari-Agustus) sudah mencapai 105\%. Fenomena tersebut di atas menarik untuk diteliti, mengapa angka kunjungan ke dokter spesialis cenderung meningkat.

Tabel 1 Trend Utilisasi Pelayanan Kesehatan PT. Jamsostek (Persero) Cab Bandung I

\begin{tabular}{lccccccccc}
\hline \multicolumn{1}{c}{ Uraian (\%) } & Parameter (\%) & \multicolumn{7}{c}{ Tahun } \\
& & 2003 & 2004 & 2005 & 2006 & 2007 & 2008 & 2009 & 2010 \\
\hline Kunj PPK I & $12-17$ & 20.18 & 15.76 & 15.98 & 13.59 & 11.35 & 11.22 & 10.95 & 12.6 \\
Kunj PPK II Rajal & $0.6-0.8$ & 2.38 & 1.69 & 2.31 & 2.05 & 1.04 & 1.76 & 1.15 & 1.28 \\
Kasus Ranap & $0.2-0.3$ & 0.25 & 0.28 & 0.31 & 0.34 & 0.18 & 0.16 & 0.18 & 0.21 \\
$\begin{array}{l}\text { Rujukan PPK I - } \\
\text { PPK II Rajal }\end{array}$ & $3-6$ & 11.79 & 10.71 & 13.30 & 15.08 & 6.67 & 18.20 & 10,53 & 10.17 \\
$\begin{array}{l}\text { Rujukan PPK II } \\
\text { Rajal - Ranap }\end{array}$ & $30-40$ & 10.50 & 16.85 & 14.74 & 16.59 & 24.10 & 7.61 & 15.87 & 16.37 \\
$\begin{array}{l}\text { Rujukan PPK I - } \\
\text { Ranap }\end{array}$ & $1-2$ & 1.24 & 1.80 & 1.96 & 2.50 & 1.61 & 1.39 & 1.67 & 1.67 \\
Ratio Klaim & 70 & 40.03 & 73.93 & 75.92 & 85.97 & 68.70 & 79.57 & 79.06 & 73.48 \\
\hline
\end{tabular}

Dari laporan juga didapat data bahwa angka kunjungan ke dokter spesialis lima besar menurut data di PT. Jamsostek Cabang Bandung I tahun 2009 adalah: Spesialis anak, Spesialis Kebidanan, Spesialis Paru, Spesialis Penyakit Dalam dan Spesialis Bedah.

PT Jamsostek (Persero) sendiri telah membuat aturan-aturan main untuk menekan klaim ratio yang tinggi, salah satunya dengan sistem dokter keluarga, dimana peserta harus berobat ke dokter keluarga/dokter umum terlebih dahulu untuk berobat. Bila dokter umum tidak mampu mengobati pasiennya, maka barulah pasien tersebut akan dirujuk ke tingkat yang lebih tinggi, yaitu dokter spesialis. Akan tetapi seringkali pasien berobat ke dokter umum hanyalah sebagai sarana untuk mendapatkan rujukan ke dokter spesialis. Misalnya seseorang dengan keluhan batuk pilek, demam, diare, maupun ISPA. Keluhan yang sebenarnya banyak disebabkan oleh virus dan akan sembuh sendiri dalam beberapa hari tanpa obat ini sebenarnya bisa diobati oleh dokter umum, namun pasien lebih memutuskan untuk berobat ke dokter spesialis. Hal itu dilakukan baik dengan cara ke dokter umum terlebih dahulu untuk meminta rujukan sebagai persyaratan prosedur ataupun langsung tanpa ikut prosedur.

Konsep diri individu berpengaruh terhadap perilaku individu. Dalam hal ini konsep diri individu peserta program JPK pada PT. Jamsostek Persero Cabang Bandung I yang mengalami sakit akan mengambil keputusan apakah ia akan memanfaatkan penanganan dari dokter spesialis atau memanfaatkan program lainnya. Konsep diri yang dimiliki individu tersebut, baik konsep diri yang 
positif maupun negatif akan memberi pengaruh terhadap pengambilan keputusan tersebut. Konsep diri yang negatif akan lebih mengarahkan individu untuk mengambil keputusan berobat ke dokter spesialis, sedangkan konsep diri individu yang positif akan mengarahkan individu untuk tidak serta merta mengambil keputusan berobat ke dokter spesialis.

Sementara itu kecemasan terhadap penyakit akan menyebabkan individu merasakan ketidaknyamanan dalam hidupnya dan akan mengganggu aktfitas kehidupan individu tersebut. Individu selalu mengharapkan agar hidupnya dalam ketenangan dan kenyamanan. Karena itu ketika ada sesuatu hal yang mengganggu kenyamanan dan mengganggu aktifitas kehidupannya, individu berusaha agar ketidaknyamanan tersebut dapat dihilangkan atau dihindari.

Salah satu yang dilakukan untuk menghilangkan ketidaknyamanan tersebut adalah melakukan konsultasi atau pengobatan kepada orang yang secara ilmu dan pengalaman memiliki kemampuan dalam memberikan penanganan medis, yaitu dokter. Dalam hal ini dokter yang dimaksudkan adalah dokter spesialis. Sehingga menurut penulis kecemasan terhadap penyakit akan mengarahkan individu untuk melakukan konsultasi atau pengobatan kepada dokter. Mengingat dalam program JPK ada fasilitas dokter spesialis, maka individu peserta program JPK yang memiliki kecemasan terhadap penyakit akan memanfaatkan fasilitas dokter spesialis.

Menurut Kamus Besar Bahasa Indonesia (KBBI), konsultasi medis adalah perundingan antara pemberi dan penerima layanan kesehatan untuk mencari penyebab terjadinya penyakit dan untuk menentukan cara-cara pengobatannya. Dalam kalimat lain, konsultasi medis adalah sarana komunikasi, informasi, dan edukasi (KIE), dimana tidak selalu KIE mengenai penyakit tersebut membutuhkan obat -tergantung penyakitnya- untuk sarana penyembuhan. Namun saat ini pengertian akan konsultasi medis atau kunjungan ke dokter mengalami pergeseran tidak semata-mata mencari kesembuhan tetapi juga sebagai gaya hidup, status sosial, dan prestise. Karena itulah peneliti merasa tertarik untuk meneliti fenomena diatas. Namun dalam penelitian ini penulis membatasi penelitian dengan meneliti Hubungan Konsep Diri Dan Kecemasan Dengan Pengambilan Keputusan Untuk Berobat Ke Dokter Spesialis (Penelitian Pada Pemanfaatan Program JPK PT. Jamsostek Persero Cabang Bandung I).

\section{Pengambilan Keputusan}

\section{Pengertian Pengambilan Keputusan}

Setiap hari orang terlibat di dalam tindakan pengambilan keputusan, bahkan mungkin harus dilakukan beberapa kali. Mulai dari masalah-masalah yang sederhana sampai dengan masalah-masalah yang kompleks dan menuntut pertimbangan banyak serta mendalam. Aktivitas pengambilan keputusan sering dilakukan orang baik disadari atau tidak disadari, sebab di dalam kehidupan sehari-hari seseorang akan banyak menemukan situasi yang tidak pasti (uncertainty).

Pengambilan keputusan ialah proses memilih atau menentukan berbagai kemungkinan di antara situasi-situasi yang tidak pasti. Pengambilan keputusan terjadi di dalam situasi-situasi yang meminta seseorang harus membuat prediksi ke depan, memilih salah satu diantara dua pilihan atau lebih, atau membuat estimasi mengenai frekuensi kejadian berdasarkan bukti-bukti yang terbatas. Pengambilan keputusan merupakan tindak lanjut pemecahan masalah, yang harus dilakukan oleh tiap manusia apapun jabatannya.

Mac Crimmon dan Taylor (1983) membedakan antara konsep pemecahan masalah dan pengambilan keputusan. Ia menyatakan dalam beberapa kasus pengambilan keputusan terutama berkaitan dengan evaluasi dan pemilihan alternatif-alternatif yang tersedia, dan pemecahan masalah berkaitan dengan keseluruhan proses formasi masalah, penyusunan alternatif, dan pemrosesan 
informasi guna mencapai pilihan yang sesuai/tepat. Pada kasus lain pemecahan masalah adalah subset pengambilan keputusan bila pemecahan masalah berkaitan dengan situasi dimana solusi-solusi yang ada sudah tepat, sedang pengambilan keputusan meliputi hal-hal yang lebih luas dan dalam konteks yang lebih penting.

\section{Dimensi Pengambilan Keputusan}

Menurut Hunsaker, dkk. (dalam Raharyanto, 2004), yang dimaksud dengan gaya pengambilan keputusan adalah cara yang dipelajari dalam memproses informasi dan pengambilan keputusan. Cara yang dipelajari tadi merupakan kebiasaan yang diperoleh melalui pengalaman masa lalu. Walaupun setiap orang mempunyai kebiasaan berpikir yang berbeda, riset yang telah dilakukan dapat mengidentifikasi pola-pola pemikiran yang umum yang digunakan dalam memproses informasi dan pengambilan keputusan yang digunakan untuk membedakan antara gaya pengambilan keputusan yang berbeda.

Menurut Hunsaker, dkk. (dalam Raharyanto, 2004), ada dua dimensi dalam pengambilan keputusan: (1) Kompleksitas informasi: seberapa banyak informasi digunakan atau seberapa kompleks permasalahan tersebut. Yang termasuk dalam kelompok ini adalah gaya fleksibel dan integrative; (2) Tingkat fokus: jumlah solusi alternatif yang dihasilkan dari informasi yang diperoleh. Yang termasuk dalam kelompok ini adalah gaya hirarkis dan decisive

Pengambilan keputusan seseorang akan meningkat tingkat kompleksitasnya ketika informasi yang lebih banyak digunakan dan solusi alternatif lebih banyak dihasilkan. Bila kita lihat di sekitar kita, kita dapat mengamati orang-orang yang cocok dengan perbedaan pola pengambilan keputusan tadi seperti: seseorang yang berkata "Ayo kita cepat buat keputusan yang cepat dan memuaskan dan kita laksanakan!” dan ada lagi yang menyukai untuk "lihat dan cari data yang memungkinkan, cari solusi-solusi yang mungkin, dan jangan kerjakan terburu-buru!”

Ekstreem dalam, baik kompleksitas ataupun fokus seringkali tidak diinginkan. Terlalu banyak informasi dapat menjadi beban dan dapat juga menyebabkan kebingungan dan kekisruhan. Terlau sedikit informasi, sebaliknya, mungkin tidak cukup untuk membuat suatu keputusan yang tepat. Satu fokus yang ekstreem dapat mengarah kepada obsesi, yang dapat mengabaikan kinerja secara keseluruhan. Banyak fokus yang ekstreem dapat mengarah kepada analisis yang berlebihan, dimana banyak kesimpulan dipertimbangkan dan tidak satupun dilaksanakan.

Dimensi kompleksitas dan fokus dapat digabungkan untuk membuat matrik yang digunakan untuk mendefinisikan empat gaya pengambilan keputusan.

Gaya decisive (Decisive Style) adalah salah satu gaya yang menggunakan data yang minimal untuk sampai pada satu keputusan yang memuaskan. Gaya Hirarki (Hirarchic Style) berlawanan dengan gaya fleksibel. Jumlah data yang besar dengan hati-hati dianalisa untuk menghasilkan satu keputusan yang optimal. Gaya integrative (Integrative Style) mirip dengan gaya hirarki yang menggunakan data maksimum, tetapi dari pada memfokuskan pada keputusan yang terbaik, gaya integrative, seperti gaya fleksibel (Flexible style), menghasilkan beberapa kesimpulan yang feasible (layak). 


\begin{tabular}{|c|c|c|c|c|}
\hline & & & & \\
\hline & & Decisive & Hirarkis & \\
\hline & Positive & Negatif & Positive & Negatif \\
\hline & Reliabel & Rigid & Rigorous & Dogmantic \\
\hline & Consistent & Simplistic & Precise & Overcontrolling \\
\hline & Fast & Shallow & Thorough & Nitpicking \\
\hline Kompleksitas & & & & \\
\hline Informasi & (minimum) & & $(m a$ & mum) \\
\hline & & Fleksibel & Integratif & \\
\hline & Positive & Negatif & Positive & Negatif \\
\hline & Intuitive & Shallow & Inventive & Complicated \\
\hline & Adaptable & Indecive & Empathetic & Nosy \\
\hline & Congenial & Fickle & Cooperative & Wishy-washy \\
\hline & & & & \\
\hline
\end{tabular}

\section{Konsep Diri}

\section{Pengertian Konsep Diri}

Burn mendefinisikan konsep diri sebagai satu gambaran campuran dari apa yang kita pikirkan mengenai pendapat orang lain tentang diri kita dan diri yang kita inginkan. Staines (dalam Burns, 1993) mendefinisikan konsep diri sebagai kesadaran terhadap hal-hal yang dipersepsikan, konsepkonsep dan evaluasi mengenai individu sebagaimana dia tampak bagi dirinya. Sedangkan menurut Calhoun (1990) konsep diri adalah apa yang diketahui tentang diri sendiri.

Konsep diri merupakan gambaran yang dimiliki seseorang akan dirinya. Merupakan apa yang diyakini seseorang ada pada dirinya, meliputi karakteristik fisik, psikologis, sosial dan emosional serta aspirasi-aspirasi dan prestasinya.

Berdasarkan beberapa uraian di atas, maka dapat disimpulkan bahwa konsep diri adalah segala hal yang kita ketahui, kita rasakan dan kita yakini ada pada diri kita, meliputi karakteristik dan bagaimana kita berhubungan dengan dunia luar, yang berkembang berdasarkan hasil persepsi dari orang lain dan dari diri sendiri.

\section{Dimensi-dimensi Konsep Diri} adalah:

Menurut Fits (1971) konsep diri seseorang bisa dari dimensi-dimensinya. Dimensi tersebut

\section{Identity self}

Identity self merupakan aspek yang paling dasar dari konsep diri, merupakan refleksi dari bentuk pertanyaan "siapakah saya?"

Elemen identitas ini akan mempengaruhi cara individu merasakan dunianya, yaitu cara bagaimana dia berespon terhadap dunia tesebut, bagaimana dia berinteraksi di dalamnya dan bagaimana pemantauan serta penilaian yang dia berikan tentang diri dan fungsi yang ia miliki. Elemen identitas atau label ini terus berkembang bersama dengan pertumbuhan kemampuan individu, aktivitas individu, keanggotaan dalam suatu kelompok serta sumber-sumber identifikasinya. 


\section{Behavioral self}

Aturan orang tua, situasi rumah dan dunia fenomenal, mengakibatkan diri behavioral self akan terasa lebih bebas ketika masih kanak-kanak. Konsekuensi dari tersebut mempengaruhi kelangsungan atau penghentian . Anak-anak tersebut akan menentukan apakah perilaku tesebut diteruskan dan dapat disatukan ke dalam identity self. Maslow (dalam Fitts, 1971) melakukan hipotesis tentang dorongan dari dalam diri seseorang untuk melakukan sesuatu. Seseorang yang mengembangkan kemampuan berbicara, merangkak, berdiri berjalan dan melompat, maka ia akan melatih kemampuan-kemampuan tersebut hingga menjadi pandai dan terbiasa melakukannya. Ketika seorang anak belajar berjalan, ia akan mendapatkan penguatan internal atau kepuasan dari mengalami suatu kemajuan, dan mengaktualisasikan kemampuan baru tersebut tanpa henti. Konsekwensi internal akan memperkuat perilaku. Perilaku sendiri merupakan sesuatu hal yang dilatih dan kemudian dikuasai, dan kemampuan seseorang melakukan suatu perilaku menjadi bagian dari identitasnya.

\section{Diri sebagai penilai (Judging Self)}

Interaksi antara Identity Self dan Behavioral Self dan integrasi keduanya ke dalam konsep diri yang total, ternyata melibatkan unsur ketiga yaitu Judging Self. Judging Self berperan sebagai pemantau, pembuat standar, pembanding dan evaluator. Judging Self juga menjadi mediator antara Identity Self dan Behavioral Self.

Judging Self tidak hanya berfungsi sebagai pemantau, akan tetapi juga pengevaluasi. Judging Self memandang pada Identity Self dan Behavioral Self dari memberi penilaian bahwa sesuatu itu adalah baik atau buruk. Jika ciri atau karakteristik tersebut merupakan aktualisasi diri, maka Judging self menyatakan bahwa hal itu adalah baik. Jika ciri atau karakter merupakan aktualisasi diri yang kemudian membuat Judging Self merasa senang dan memberitahu bahwa hal tersebut sudah cukup bagus. Bentuk standar dimana terdapat Judging Self tergantung pada pengembangan nilai aktualisasi diri yang memiliki konsistensi dalam masyarakat dan budaya. Hal ini bukan berarti bahwa orang tua atau orang lain yang berpengaruh menentukan nilai-nilai aktualisasi diri seseorang. Mungkin saja seorang anak melakukan nilai-nilai dan standar-standar yang merupakan hasil adopsi, walaupun kenyataannya nilai-nilai tersebut menimbulkan konflik dengan nilai aktualisasi dirinya (Fitts, 1971).

Standar spesifik yang digunanakan dalam Judging Self adalah pengertian absolut (absolute manner) dan pengertian relative (relative manner) atau pengertian komparatif (komparatif manner). Pengertian absolute mengatakan "saya orang yang baik dan apapun yang saya lakukan ini adalah baik". Pengertian relatif mengatakan "apakah saya baik seperti seharusnya atau saya seperti yang saya inginkan atau seperti yang diinginkan orang lain”. Contohnya bila saya adalah penulis. Jika menulis atau menjadi penulis adalah suatu hal yang penting bagi saya dan jika saya menganggap bahwa menjadi penulis adalah sesuatu yang baik, maka hal ini (sebagai penulis) meninggikan harga diri saya, selanjutnya akan mengaktualisasikan diri saya, sehingga hal ini menjadi bagian yang penting bagi identity self dan behavioral self (Fitts, 1971)

Judging Self juga menentukan kepuasan diri atau mengembangkan toleransi terhadap diri. Kepuasan diri yang rendah cenderung mengakibatkan kesadaran diri yang rendah, self esteem yang rendah dan ketidakpercayaan diri. Kepuasan diri yang tinggi menjadi dasar yang realistik bagi kesadaran diri yang tinggi. 


\section{Kecemasan}

\section{Pengertian Kecemasan}

Kecemasan merupakan suatu perasaan yang tidak menyenangkan yang dialami manusia. Kecemasan dapat mempengaruhi seseorang dalam menjalani kehidupannya. Mc Neil, dkk. (1994) mengatakan bahwa kecemasan merupakan keadaan emosional yang ditandai dengan adanya laporan secara verbal mengenai keadaan distress -misalnya ketakutan akan sesuatu yang akan terjadi, khawatir-, keadaan fisiologis -misalnya meningkatnya denyut jantung-, dan perilaku -misalnya menghindar-, serta gangguan pada proses kognitif -misalnya kesadaran yang berlebihan terhadap tanda-tanda bahaya yang ada di lingkungan-.

Orang yang sedang dalam keadaan cemas memiliki ambang batas yang rendah terhadap respons-respons emosional yang lain. Atau dengan kalimat lain, dapat memacu terjadinya emosi yang lain, contohnya orang yang sedang dalam keadaan cemas, akan lebih mudah marah atau sebaliknya mereka juga lebih mudah bereaksi secara berlebihan terhadap stimulus-stimulus yang menyenangkan. Selain itu, orang yang cemas juga dalam keadaan berbagai macam perasaan dan perilakunya tidak dapat diprediksi (Kagan \& Havemann, 1976)

\section{Komponen Kecemasan}

Kecemasan memiliki 3 komponen yaitu komponen kognisi, perilaku, dan respon fisiologis (Mc Neil, dkk., 1994).

Komponen kognisi: (a) Berbicara pada diri sendiri mengenai hal-hal yang negatif (negatif self-talk); (b) Kekhawatiran yang berlebihan, bahkan seringkali dalam derajat yang tidak masuk akal (obsessive worrying); (c) Kepercayaan pada kemampuan diri untuk menyelesaikan suatu tugas rendah (low self-efficacy); (d) Penyangkalan diri (self-abnegation).

Ada tiga (3) kategori kecemasan yang berhubungan dengan komponen kognitif, yaitu: (a) Individu menjadi selektif terhadap informasi-informasi yang berhubungan dengan bahaya; (b) Menunjukkan adanya ingatan terhadap informasi yang berhubungan dengan bahaya; (c) Menunjukkan adanya bias dalam menginterpretasikan informasi-informasi yang ambigu dan memiliki arti dapat menimbulkan bahaya.

\section{Komponen Respon fisiologis}

Kecemasan yang diasosiasikan dengan perubahan-perubahan pada organ dan sistem tubuh, seperti pada sistem saraf, sistem endoktrin, denyut jantung, aliran darah, dll. Komponen Perilaku: (a) Menarik diri (withdrawal), ada dua macam; menghindar (avoidance) terhadap objek atau situasi, dan melarikan diri (escape). Disini individu menghadapi obyek atau situasi tersebut terlebih dahulu, baru kemudian meninggalkannya sebelum waktunya; (b) Diam (immobility) ada dua macam; pertama membeku (freezing) diam tetapi tetap waspada atau penuh perhatian, jadi walaupun merasa tidak berdaya atau takut tetapi tetap menigkatkan kesadaran akan bahaya yang mungkin. Yang kedua tidak berespon (unresponsive), organisme tampak seperti mati. Respons-respons kecemasan seperti ini jarang ada pada manusia, tetapi dapat dilihat pada reaksi yang ekstrim terhadap sumber-sumber stress yang utama; (c) Tunduk/patuh (submission). Pada submission, organisme berusaha untuk mengelakkan serangan pada dirinya atau berusaha untuk menenangkan organisme yang terancam. Pada manusia, penenangan dapat diamati dalam setiap interaksi sosial, seperti situasi dimana individu dengan status yang lebih rendah berusaha untuk menentramkan orang dengan status yang lebih tinggi, dengan cara menghindari kontak mata; (d) Agresi (aggression). Respon terhadap ancaman yang diasosiasikan dengan agresi dapat menjadi adaptif, yaitu dapat mengurangi serangan dari orang lain. Contohnya verbal attack (serangan secara verbal) dan threats (ancaman). 


\section{Definisi Operasional Variabel}

Untuk menjelaskan pengertian dari variabel-variabel penelitian yang terlibat dalam hipotesis penelitian ini, maka dirumuskan definisi operasional setiap variabel sebagai berikut: (1) Konsep diri adalah: pandangan terhadap diri sendiri yang meliputi dimensi Identity Self, Behavioral Self, dan Judging Self, diukur dengan skala konsep diri; (2) Kecemasan adalah: keadaan atau kondisi individu yang ditandai dengan perasaan yang tidak menyenangkan yang nampak pada kognisi, respon fisiologis dan perilakunya karena ada ancaman-ancaman tertentu, yang diukur dengan skala kecemasan; (3) Pengambilan keputusan untuk berobat ke dokter spesialis pada program JPK adalah: proses memilih atau menentukan berbagai kemungkinan di antara situasi-situasi yang tidak pasti dengan menggunakan dimensi kompleksitas informasi dan dimensi tingkat fokus, yang diukur dengan skala pengambilan keputusan.

\section{Populasi dan Sampel Penelitian}

Dalam penelitian ini yang menjadi populasi adalah seluruh peserta program JPK PT. Jamsostek Persero Cabang Bandung I yang telah berobat ke dokter umum rata-rata perbulan pada periode tahun 2009 yaitu berjumlah 5.932 peserta, terdiri dari 1.225 perusahaan. Sedangkan sampel penelitian diambil dari pasien yang berobat ke RS Hasan Sadikin dan RS Santo Yusup yang merupakan perwakilan dari RS pemerintah dan swasta yang bekerjasama dengan PT. Jamsostek Bandung I dengan jumlah kunjungan pasien Jamsostek terbanyak di antara lima rumah sakit lainnya yang juga merupakan provider PT. Jamsostek (Persero) Bandung I.

\section{Teknik pengambilan sampel}

Tehnik pengambilan sampel yang digunakan dalam penelitian ini adalah tehnik incidental purposive sampling. Kriteria responden yaitu peserta Program JPK Jamsostek yang sudah pernah atau sedang berobat ke dokter spesialis.

\section{Instrumen}

Untuk penelitian ini digunakan 3 instrumen penelitian, yaitu skala konsep diri, skala kecemasan, dan skala pengambilan keputusan untuk berobat ke dokter spesialis pada program JPK.

Konsep diri; dalam penelitian ini digunakan pengukuran konsep diri dengan membuat kuisioner mengacu kepada dimensi konsep diri yaitu Identity Self, Behavioral Self, dan Judging Self.

Kecemasan; dalam penelitian ini digunakan pengukuran kecemasan dengan membuat kuisioner kecemasan yang meliputi komponen kognisi, respon fisiologis, dan prilaku.

Pengambilan keputusan berobat ke dokter spesialis pada program JPK; Pengukuran pengambilan keputusan berobat ke dokter spesialis dibuat dengan menggunakan kuesioner pengambilan keputusan yang meliputi dimesi kompleksitas informasi dan dimensi tingkat fokus.

\section{Analisis Data Penelitian}

Pengujian hipotesis penelitian ini secara langsung dilakukan dengan uji statistik korelasi parsial untuk menguji hipotesis satu dan dua dan tehnik regresi ganda untuk menguji hipotesis tiga.

Berikut hasil analisis data penelitian: (1) Korelasi variabel kecemasan dengan variabel pengambilan keputusan berobat ke dokter spesialis. Dari hasil analisis diperoleh nilai korelasi sebesar 0,371 dengan nilai signifikan $=0,000$. Dengan demikian korelasi signifikan. Dari penghitungan 
tersebut maka dapat disimpulkan bahwa ada hubungan yang positif dan signifikan antara variabel kecemasan dengan variable pengambilan keputusan berobat ke dokter spesialis; (2) Korelasi variabel konsep diri dengan variabel pengambilan keputusan berobat ke dokter spesialis. Dari hasil analisis diperoleh nilai korelasi sebesar 0,412 dengan nilai sig $=0,000$. Dengan demikian korelasi signifikan. Dari penghitungan tersebut maka dapat disimpulkan bahwa ada hubungan yang positif dan signifikan antara variabel konsep diri dengan variable pengambilan keputusan berobat ke dokter spesialis.(3) Korelasi variabel kecemasan dan variabel konsep diri secara bersama-sama dengan variabel pengambilan keputusan berobat ke dokter spesialis.

Dari hasil analisis diperoleh nilai korelasi sebesar 0,513 dengan nilai sig $=0,000$. Dengan demikian korelasi signifikan. Dari penghitungan tersebut maka dapat disimpulkan bahwa ada hubungan yang positif dan signifikan antara variabel kecemasan dan variable konsep diri secara bersama-sama dengan variable pengambilan keputusan berobat ke dokter spesialis.

\section{SIMPULAN}

Berdasarkan hasil pengolahan dan analisis data penelitian yang telah dilakukan dapat disimpulkan bahwa: ada hubungan antara konsep diri dengan pengambilan keputusan untuk berobat ke dokter spesialis, ada hubungan antara kecemasan dengan pengambilan keputusan untuk berobat ke dokter spesialis, dan ada hubungan antara konsep diri dan kecemasan secara bersama-sama dengan pengambilan keputusan untuk berobat ke dokter spesialis.

Hasil uji statistik yang telah dilakukan pada penelitian ini menunjukkan bahwa baik variabel kecemasan maupun variable konsep diri kedua-duanya memiliki korelasi yang positif dan signifikan dengan variable pengambilan keputusan berobat ke dokter spesialis. Demikian juga kedua varibel tersebut secara bersama-sama berkorelasi positif dan signifikan dengan variable pengambilan keputusan berobat ke dokter spesialis. Namun bila dilihat besaran korelasi antara kedua variable independent, maka terlihat variable konsep diri lebih besar pengaruhnya terhadap pengambilan keputusan berobat ke dokter spesialis. Hal ini menurut penulis karena konsep diri yang dimiliki peserta begitu dominan.

\section{Saran}

Berdasarkan penelitian ini, penulis mengajukan beberapa saran bagi beberapa pihak.

\section{Bagi PT. Jamsostek (Persero)}

PT. Jamsostek (Persero) perlu memperhatikan aspek psikologis dari pasiennya dan tidak semata-mata dari sisi bisnis perusahaan. Tingkat kecemasan pasien terhadap penyakitnya memang cukup tinggi sehingga membuat pasien segera memutuskan berobat ke dokter spesialis bila ada perubahan pada kesehatannya. Untuk itu penulis menyarankan kepada PT Jamsostek (Persero) untuk memberikan edukasi kepada pesertanya tentang tata cara menangani penyakit, terutama pertolongan pertama pada gejala awal penyakit, pada penyakit infeksi, dan penyakit degenerative yang memerlukan pengobatan rutin.

PT. Jamsostek (Persero) perlu memberikan edukasi kepada pesertanya agar tingkat kunjungan ke dokter spesialis dapat turun dan sesuai dengan parameter yang menjadi standar keberhasilan PT. Jamsostek (Persero). Edukasi itu dapat dilakukan dengan beberapa cara, antara lain:

- Lakukan penyuluhan ke peserta tidak semata-mata menerangkan tentang prosedur dan benefityang didapat peserta. Tetapi juga tentang memberikan pendidikan kepada peserta tentang pemanfaatan ke dokter spesialis, sehingga peserta tidak spesialist minded 
- $\quad$ Membuat brosur/pamflet untuk diberikan kepada peserta tentang pemanfaatan dokter spesialis yang baik dan benar.

- Memberikan pemahaman kepada peserta tentang obat-obatan generik dan obat standar Jamsostek, bahwa semua obat sama baiknya sehingga pasien tidak berfikir bahwa obat dari dokter umum tidak manjur untuk menyembuhkan penyakitnya.

- Secara periodik dilakukan pertemuan dengan dokter spesialis dari rumah sakit provider PT. Jamsostek (Persero) untuk memberikan pemahaman kepada dokter spesialis agar mengembalikan pasien peserta Jamsostek kepada dokter keluarga selaku gate keeper PT. Jamsostek (Persero) apabila pengobatan/terapi sudah dilakukan secara rutin serta agar kunjungan ke dokter spesialis berkurang.

- $\quad$ Yang tidak kalah penting, PT Jamsostek harus membuat suatu sistem agar dokter spesialis tidak merasa 'income'nya berkurang bila pasien dikembalikan ke dokter umum.

\section{Bagi Provider PT. Jamsostek (rumah sakit dan dokter spesialis)}

Mengingat tingginya tingkat kecemasan pasien terhadap penyakitnya, dan konsep diri pasien yang berlebihan, sebaiknya dokter spesialis di rumah sakit provider Jamsostek turut memberikan edukasi kepada pasiennya tentang bagaimana menangani penyakitnya sendiri sehingga tidak ketergantungan kepada dokternya. Selain itu penulis menyarankan agar dokter spesialis mengembalikan pasien yang sudah dianggap stabil ke dokter umum dengan memberikan terapinya tanpa ada perasaan 'income'nya akan berkurang. Salah satu alasan tingginya angka kunjungan ke dokter spesialis adalah adanya kepercayaan dari pasien bahwa obat paten lebih baik dari obat generik. Karena itu peneliti menyarankan agar setiap kali meresepkan obat, dokter juga melakukan edukasi kepada pasiennya tentang manfaat dan kerugian obat yang diresepkan. Diutamakan agar memberikan obat yang sesuai standar Jamsostek agar ketidak-percayaan pasien terhadap obat generik berkurang.

\section{Bagi Peserta Program JPK Jamsostek}

Konsep diri yang salah selama ini turut membuat andil tingginya angka kunjungan ke dokter spesialis. Karena itu penulis menyarankan agar sebelum mengambil keputusan berobat ke dokter spesialis, pasien sebaiknya lebih dahulu mencari informasi tentang penyakit yang dideritanya sehingga apabila ia berobat ke dokter manapun (umum/spesialis) ia telah mendapatkan gambaran tentang terapi yang akan dilakukan oleh dokternya. Penulis juga menyarankan agar pasien tidak terlalu innocent dan selalu melakukan second opinion atau third opinion terhadap terapi yang dilakukan oleh dokter spesialisnya.

\section{Bagi Praktisi Kesehatan}

Sebaiknya dibuat suatu sistim atau kalau perlu Undang-undang tentang sistim rujukan sehingga dokter umum tidak terlalu sering merujuk pasiennya. Ada beberapa cara yang dapat dilakukan:

- Dimulai dari calon sarjana kedokteran, salah satu syarat kelulusan, selain keterampilan di bidangnya, ia juga harus telah membina dan memberikan penyuluhan tentang promosi kesehatan sedikitnya satu kecamatan.

- Dokter umum lebih mendekatkan diri ke masyarakat melalui program tetap. Misalnya penyuluhan ke group arisan, pengajian, posyandu dan lain-lain

- $\quad$ Dibuat paket pembiayaan per diagnose (bukan per kunjungan) pada tingkat dokter spesialis. Hal ini akan membuat kerja dokter spesialis lebih efisien. Misal untuk diagnosa hipertensi, paket biayanya adalah 500 ribu rupiah.

- Dokter umum sebaiknya diberikan insentif/reward apabila ia telah berhasil menangani sedikitnya 100 kasus. Hal ini akan membuat dokter umum tidak serta merta merujuk pasien ke dokter spesialis. Sedangkan pada kasus yang tidak/belum selesai sebaiknya dilakukan review (telepon pasiennya, atau kunjungi rumahnya) 
Ada baiknya Dokter Umum meningkatkan kemampuannya sehingga pasiennya tidak 'lari' ke dokter spesialis. Dokter Umum pun sebaiknya memberikan edukasi kepada pasiennya tentang perawatan penyakitnya agar pasien tidak minta dirujuk ke dokter spesialis.

\section{DAFTAR PUSTAKA}

Balota, David A, \& Marsh, Elizabeth J. (2003), Kognitive Psikology key reading. New York: Taylor and Friend Books Inc.

Chaplin, J.P. (1999). Kamus Lengkap Psikologi. (Edisi 5). Jakarta: PT Raja Grafindo Persada. (5th Ed).

Eggen, Paul. \& Kauchak, Don., (1992). Educational Psychology Windows on Classrooms. Sixth Edition. New Jersey, Prentice Hall.

Franken, Robert E., (2002). Human Motivation. USA. Wadsworth Thomson Learning.

Gordon, R. (1996), Organizational Behavior: A diagnostic Approach. (5th Ed) New Jersey: prentice Hall, Inc.

Himpunan Peraturan Perundang-undangan (2010). Undang-Undang Praktek Kedokteran Edisi 2010. Bandung, Fokusmedia.

Hunsaker, Philip L. \& Alessandra, Anthony J., The art of Managing People, Simon \& Schuster Inc., New York, 1980.

Ilyas, Yaslis. (2003). “Kiat Sukses Mananjemen Tim Kerja”: Jakarta: PT Gramedia Pustaka Utama.

Kagan, J, \& Havemann, E. (1976). Psychology: an introduction. San Diego: Harcourt Brace Jovanovich

Kagan, J., \& Segal,J. (1988) Psychology; an introduction (6th ed). San Diego: Harcourt Brace Jovanovich

Kerlinger, Fred N. Asas-asas Penelitian Behavioral, Gajah Mada University Press, 1995

Leithenberg, H. (1990), Handbook of social and evaluation Anxiety. New York: Plenum Press.

Lukluk, A. \& Bandiyah, S. (2008). Psikologi Kesehatan. Yogyakarta, Mitra Cendikia

Matlin, M.W. (2002), Cognition (5th Ed) Singapore: Thomson Learning.

Mc Neil, D.W. Tur, C.L., \& Ries, B.J. (1994), Anxiety and fear. Dalam Ramachandran, Vs. (ed), Encylopedia of human Behavior (Vol 1, pp 151-163) San Diego: Academic Press Inc.

Morgan, C.T. et.al (1986). Introcuction To Psychology. (7th ed) Singapore: Mc Graw-Hill

Papalia, D.E. ., \& Olds, S.W. (1987) Psychology. Singapore: Mc Graw-Hill.

Power, M. \& Dalgleish, T. (1997) Cognition and emotion: from order to disorder. UK. Psychology Press.

PT. Jamsostek (Persero). Surat Edaran Nomor SE/05/0596 Tentang Pengendalian Pemanfaatan Pelaksana Pelayanan Kesehatan (PPK). Jakarta. 
PT. Jamsostek (Persero). Undang-undang Nomor 3 tahun 1992 tentang Jaminan Sosial Tenaga Kerja. Jakarta.

Rabin, Carolin aand Ward, Sandra. (2001). Explaining Restrospective Reports of Symtoms in Patien Undergoing Chemoterapy: Anxiety, Initial Symptom Experience, and Posttreatment Symtoms. The Journal, Madison, University of Wisconsin.

Raharyanto, Tri Heru. (2004). Pengambilan keputusan dalam “Human Relation”. Jakarta: Universitas Mercu Buana.

Rakhmat, Jalaludin (2004). Psikologi Komunikasi. Edisi Revisi. Bandung, PT Remaja Rosdakarya

Reisberg, Daniel. (2000). Cognition-eksploring the science of the mind (second edition). New York, London: Nourton \& company

Rida, Akram, Dr. (2005). “Making Choice 9 Langkah Mengambil Keputusan dengan Pendekatan Manajemen Diri”. Bandung: Hikmah (PT Mizan Publika).

Riegler, Gregory Robinson., Riegler, Bridget Robinson. Kognitive Psychology Applying the Science of the Mind (second edition). New York: Pearson Internasional Edition

Robbins, SP (1988), Essential of Organizational Behavior (2nd ed). New Jersey: Prentice Hall, Inc.

Robbins, Stephen P (1998). Perilaku Organisasi: Konsep,Kontroversi, Aplikasi, Jilid I. Jakarta: PT Prenhallindo.

Robbins, Stephen P., (1991), Organizational Behavior: Concept, Controversies, and Application, Prentice-Hall Editions, Englewood Cliffs, New Jersey.

Santoso, siti Sapardiayah., Gotama, I.B Indra., dan Waluyo, Imam., (2004). "Perserpsi Masyarakat Terhadap Shigela (Disentri) di Jakarta Utara” Artikel Media Litbang Kesehatan Vol XIV nomor 3 tahun 2004.

Santrock, J.W. (2001). Educational Psychology. Singapore, McGraw-Hill.

Singgih D. Gunarsa, (2006). Psikologi Perkembangan Anak dan Remaja. Jakarta: PT BPK Gunung Mulia

Smet, Bart. (1994). “Psikologi Kesehatan”: Jakarta: PT Gramedia Widiasarana Indonesia (Grasindo).

Stenberg, Robert J. (2008), Psikologi Kognitif (edisi keempat). Jakarta: Pustaka Pelajar

Suharnan, (2005), Psikologi Kognitif, Surabaya, Srikandi

Suharnan, Prof, dr, MS, (1998) Psikologi Kognitif (edisi revisi), Surabaya: Srikandi

Surat Edaran nomor SE/05/0596 Tentang "Pengendalian Pemanfaatan Pelaksana Pelayanan Kesehatan (PPK) ditandatangani oleh Drs. Sukarna Suriatmadja, MSc, Direktur Pembinaan dan Pelayanan PT Jamsostek (Persero).

Woolfolk, A.E. (2004). Educational Psychology (7th Ed). Singapore: Allyn Bacon. 